\title{
Erratum to: The Influence of Retail \\ Management's Use of Social Power \\ on Corporate Ethical Values, Employee \\ Commitment, and Performance
}

Arne Nygaard
Harald Biong

\section{Erratum to: J Bus Ethics}

DOI 10.1007/s10551-010-0497-y

"The Influence of Retail Management's Use of Social Power on Corporate Ethical Values, Employee Commitment, and Performance" has been republished with DOI 10.1007/s10551-0100523-0. In the republication the correct author group: Harald Biong, Arne Nygaard and Ragnhild Silkoset has been published.

The original article was erroneously published in the Journal of Business Ethics, volume 97, issue 1, November (II), 2010.

The republication of the above mentioned article will be published in the Journal of Business Ethics, volume 97, issue 3, December (II), 2010.
The publisher wishes to apologize to the authors for any inconvenience caused.

Arne Nygaard and Harald Biong

Department of Marketing, BI Norwegian School of Management, Centre for Advanced Research in Retailing, 0442 Oslo, Norway

E-mail:arne.nygaard@bi.no

Harald Biong

E-mail: harald.biong@bi.no

The online version of the original article can be found under doi:10.1007/s10551-010-0497- $y$. 